(C) Booij L., 2018

UDC 546.17:616-053.3-009.614

DOI - https://doi.org/10.14300/mnnc.2018.13103

ISSN - 2073-8137

\title{
THE HISTORY OF NITROUS OXIDE. SHOULD IT STILL BE USED IN PEDIATRIC MEDICINE? (PART II)
}

Booij Leo H. D. Hj.

\author{
Radboud University Medical Centre, Nijmegen, The Netherlands
}

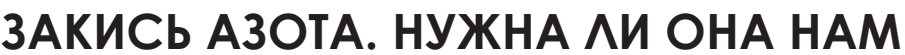
ПРИ ПРОВЕАЕНИИ АНЕСТЕЗИИ У АЕТЕЙ? (ЧАСТЬ II)*

ヘ. Бой

МеАицинский Центр РаАбурАского Университета, Ниемеген, Нилерланаы

Nitrous oxide $\left(\mathrm{N}_{2} \mathrm{O}\right)$ has long been used for providing anesthesia. Despite its beneficial properties were discovered significant adverse effects on the human body. This suggests that the influence of this gas lies not only in changing the function of the nervous system, but also to a large extent due to the impact on the human reproductive system, leading to the development of teratogenic effects in long exposures. Features of the metabolic gas in childhood can lead to seizures and mental disturbances in patients. The instability of hemodynamics at high doses and a tendency to hypoxic brain damage make this anesthetic unsafe in children.

Keywords: pediatric anesthesia, pediatric surgery, anesthesia associated complications in children, drugs adverse reactions

Закись азота $\left(\mathrm{N}_{2} \mathrm{O}\right)$ давно применяется для оказания анестезиологического пособия. Несмотря на ее полезные свойства, были обнаружены значительные неблагоприятные воздействия на человеческий организм. Это позволило предположить, что влияние газа кроется не только в изменении функции нервной системы, но вследствие воздействия на репродуктивную систему человека приводит к развитию тератогенных эффектов при длительной экспозиции. Особенности метаболизма газа в детском возрасте могут привести к возникновению судорог и нарушений психики у пациентов. Нестабильность гемодинамики при высоких дозировках и склонность к гипоксическому повреждению головного мозга делают данный анестетик небезопасным в детской практике. Несмотря на большой массив подтверждающих данную теорию фактов, не все специалисты готовы отказаться от привычного способа анестезиологического пособия.

Ключевые слова: педиатрическая анестезия, детская хирургия, осложнения анестезии у детей, побочные эффекты лекарственных средств

For citation: Booij L. THE HISTORY OF NITROUS OXIDE. SHOULD IT STILL BE USED IN PEDIATRIC MEDICINE? (PART II). Medical News of North Caucasus. 2018;13(3):549-554. DOI - https://doi.org/10.14300/mnnc.2018.13103

Для цитирования: БоЙ Л. ЗАКИСЬ АЗОТА. НУЖНА ЛИ ОНА НАМ ПРИ ПРОВЕДЕНИИ АНЕСТЕЗИИ У ДЕТЕЙ? (ЧАСТЬ II). Медицинский вестник Северного Кавказа. 2018;13(3):549-554. DOI - https://doi.org/10.14300/mnnc.2018.13103

$\mathrm{N}_{2} \mathrm{O}$ - Nitrous oxide

PONV - Postoperative Nausea and Vomiting

\section{Teratogenicity, toxicity and depression}

of fertility in personnel exposed to $\mathrm{N}_{2} \mathrm{O}$

A national survey amongst 49585 operating room personnel indicated in 1974 that the female members of the operating-room team were subject to increased risks of spontaneous abortion, congenital abnormalities in their children, cancer, renal and hepatic disease [1]. No increased rate of cancer or renal disease was seen among the male operating-room. personnel, but a similar increase in the incidence of hepatic disease could be demonstrated. An increased risk of congenital abnormalities was also present in the children of the male operating-room personnel. In 1979 was it demonstrated that in three large retrospective surveys in the United States and the United
Kingdom an increased incidence of spontaneous abortion among female physicians working in the operating room occurred [2]. The study also revealed that live-born children of female physicians exposed in the operating room had substantially more congenital abnormalities.

In 1986 was a greater incidence of first and second trimester spontaneous abortions found in patients receiving $\mathrm{N}_{2} \mathrm{O}$ [3]. In 1999 was it shown that in Swedish Midwifes exposure to $\mathrm{N}_{2} \mathrm{O}$ resulted in reduced birth weight and an increase in the odds of infants being small for gestational age [4].

\section{Infertility}

A study in 1992 amongst female dental assistants found reduced fertility in those exposed to high levels of

\footnotetext{
* Часть I была опубликована в журнале «Медицинский вестник Северного Кавказа», 2017;12(3):347-354
} 
$\mathrm{N}_{2} \mathrm{O}$ [5]. A relationship between increased risk of subfertility or spontaneous abortion and work in medical occupations and with some specific medical exposures, such as nitrous oxide, was found in a number of studies [6]. $\mathrm{N}_{2} \mathrm{O}$ also proved to be genotoxic [7]. In 1976 was a toxic effect of $\mathrm{N}_{2} \mathrm{O}$ on spermatogenesis in rats found, with a decrease in spermatozoa and malformations in them [8]. In 1996 was it found in a study in 3985 Swedish midwifes that they, if they were exposed to nitrous oxide 30 or more times per month, had a reduced fertility [9]. Since then the study was confined to women who had achieved pregnancy, these results could underestimate the true effect if the exposures also increase the risk of sterility.

\section{Spontaneous abortion}

A study in 1971 showed that about $30 \%$ of pregnancies in operation room personnel ended in spontaneous miscarriage, compared to $8 \%$ in a control group [10]. In 1970 was it found that in a group of female anesthetists and operating-room nurses the percentage of spontaneous abortions rose from about 10 percent before employment to 20 percent after employment [11]. In addition, the group showed a significant increase in premature deliveries as well as an increase in the number of female births. Others found similar figures [12]. Spontaneous abortions among anesthetists occurred in nearly 40 percent of the pregnancies.

In 1972 one of the earliest large-scale epidemiological studies examining a relationship between $\mathrm{N}_{2} \mathrm{O}$ exposure and abortion was published [13]. The investigators surveyed female anesthetists in the United Kingdom and reported a significantly greater frequency of spontaneous abortion among anesthetists $(18.2 \%)$ than among control subjects (14.7\%). Among 2291 pregnancies reported by UK dentists, there was a significantly greater rate of spontaneous abortion relative to controls (12.8\% vs. $10.9 \%$ ) [14]. Others studied 30547 female dental assistants in the US [15]. The rate of spontaneous abortion was 1.7 to 2.3 times greater for female dental assistants who were exposed to anesthetic gases in the year before conception than for those who were not exposed. For wives of male dentists who were heavily exposed to anesthetics, the increase in spontaneous abortion rate was 1.5 -fold. A 1985 study showed a $30 \%$ increased risk of spontaneous abortion for women working in the operating room[16]. In a study conducted in California in 1995 examined 1465 respondents whose most recent pregnancy was conceived while working full-time as dental assistant. They reported significantly more spontaneous abortions among women who worked with $\mathrm{N}_{2} \mathrm{O}$ for 3 or more hours per week without scavenging equipment than among respondents exposed to $\mathrm{N}_{2} \mathrm{O}$ that used scavenging equipment [17] It has also been demonstrated that $\mathrm{N}_{2} \mathrm{O}$ during surgery not only escapes via the breathing system, but also from the wounds, especially with open abdomen or thorax. This exposes the surgeon and assistants to $\mathrm{N}_{2} \mathrm{O}$ despite scavenging of the respiratory gases. A survey of health conditions among 2.798 male members of the American Society of Oral Surgeons showed a greater incidence of spontaneous abortions among the wives of exposed dentists than the wives of unexposed dentists $(p<0.01)$. In 1999 indicated a study that in Swedish midwifes also working night shifts and a high work load increased the risk of spontaneous abortion [18].

\section{Malformations}

Animal studies have linked $\mathrm{N}_{2} \mathrm{O}$ with abnormalities in the maintenance of mitochondrial quality [19] and mitochondrial function [20] leading to abnormalities in synaptic dynamics in the developing brain. Anesthetic gases slow the rate of cell division and increase the rate of abnormal cell formation and chromosomal aberrations [21] $\mathrm{N}_{2} \mathrm{O}$ has also been shown to cause fetal malformations, to increase fetal deaths and to decrease litter size in laboratory animals [22, 23]. A variety of animal experiments demonstrating apoptosis or dendrite growth failure, followed by observational cohort studies of neonates or young children who have received multiple anesthetics shows a link with poorer neurological outcomes [24]. However, until now have brief episodes of $\mathrm{N}_{2} \mathrm{O}$ exposure to mothers in the delivery suite or to medical personnel not been significantly linked with developmental problems. Teratogenic effects of $\mathrm{N}_{2} \mathrm{O}$ in Sprague-Dawley rats was demonstrated in 1967 [25]. These were primarily skeletal changes. Fetal resorptions (similar to spontaneous abortions in man), decreased birth weight, and decreased crown-rump length have been demonstrated in 1974 when pregnant hamsters were exposed to a combination of halothane and $\mathrm{N}_{2} \mathrm{O}$ $[26,27]$. Others have shown embryo toxicity in rats at levels as low as $0.1 \%$ or 1000 ppm [28].

\section{Malignancies}

In 1968 was it demonstrated that anesthesiologists had a much higher rates of suicide and lymphoid as well as reticuloendothelial cancers [29]. A study in nurse anesthetists in 1973 indicated a 3 times higher incidence of all sorts of cancers [30].

Increase in spontaneous abortion rate in health care workers was not observed [31]. A study reported that $\mathrm{N}_{2} \mathrm{O}$ inhibited $50 \%$ of cell growth in leukemic cells at 1 atmosphere, this effects was greater in combination with 5-fluorouracil [32]. Also the growth suppression of leukemic cells by hyperbaric nitrous oxide for a longer time has been studied [33]. An in vitro study with 4 cancer cell-lines (CCRF-CEM, K562, A549 and MDA-MB-231) demonstrated that administration of $\mathrm{N}_{2} \mathrm{O}$ at hyperbaric pressures made not difference [34].

\section{Nausea and vomiting}

Meta-analyses of published work have found that omission of nitrous oxide reduces the risk of PONV by nearly $30 \%$ and that the maximal effect of nitrous oxide omission is seen in female patients. $\mathrm{N}_{2} \mathrm{O}$ increases the incidence of postoperative nausea and vomiting [35, 36, $37,38,39]$. A Cochrane analysis in 2010 confirmed the higher incidence of nauseas and vomiting in patients receiving $\mathrm{N}_{2} \mathrm{O}$, especially in female [40]. The incidence of nausea and vomiting is as high as with other inhalants, but higher than with total intravenous anesthesia [41]. Similar results were obtained with studies in primates. A recent study once more demonstrated that $\mathrm{N}_{2} \mathrm{O}$ is an independent risk factor for postoperative nausea and vomiting [42]

\section{The use of nitrous oxide in children}

In children does $\mathrm{N}_{2} \mathrm{O}$ accelerate the onset of effect of other inhaled anesthetics (second gas effect) [43]. This leads to faster unconsciousness [44]. The effects on the needed concentrations is additive, reducing the needed concentration of the other anesthetic agents [45, 46, 47, $48,49]$. therefore use of $60-70 \% \mathrm{~N}_{2} \mathrm{O}$ reduces the exposure to more toxic inhalation anesthetics. The effect of intravenous anesthetics is enhanced by co-administration of $\mathrm{N}_{2} \mathrm{O}[50,51]$. The same holds for sedatives [52, 53], but not for opioids [54], except probably for remifentanil [55]. The adverse effects described in adults can also happen in children.

In 2003 was it demonstrated that in pediatric patients the middle ear pressure increased during $\mathrm{N}_{2} \mathrm{O}$ anesthesia [56]. Personnel involved may be harmed by the use of $\mathrm{N}_{2} \mathrm{O}$ in pediatrics. One of the major problems especially in pediatric use is the leakage and wasting of nitrous oxide into the environment. 
Contrary to what occurs in adults, the addition of nitrous oxide to anesthesia with 1 MAC of halothane or isoflurane in children does not result in cardiovascular signs secondary to sympathetic stimulation [57]. The addition of nitrous oxide in children causes a decrease in heart rate, mean arterial pressure and consequent reduction in cardiac output. Systolic volume and ejection fraction do not change with the addition of nitrous oxide. The combination of nitrous oxide and volatile anesthetic agents reduces the incidence of hypotension when compared to the administration of these agents alone, at equipotent dose [58]. $\mathrm{N}_{2} \mathrm{O}$ decreases the oxygen content and thus, at intubation, does hypoxia occur more rapidly [59]. During emergence of anesthesia it does not have such an effect [60]. Therefore is atelectasis at the end of anesthesia not due to $\mathrm{N}_{2} \mathrm{O}$, but is commonly due to residual paralysis caused by the use of muscle relaxants.

$\mathrm{N}_{2} \mathrm{O}$ is used as a sedative in pediatric patients [61, 62]. An example is the administration of $\mathrm{N}_{2} \mathrm{O}$ during dental treatment $[63,64]$. Especially its rapid complete recovery is an advantage. However the circumstances in many dental clinics do not provide scavenging of wast gases.

Also in reduction of bone fractures and other minor treatments is it frequently used $[65,66,67,68,69,70$, 71]. However, it may result in an higher incidence of nausea and vomiting and also in an elevated homocysteine concentration and inactivation of methionine synthase and its effects.

Children with deficiencies of the enzyme methionine synthase display megaloblastic changes, growth retardation, psychomotor retardation, neurologic problems, elevated homocysteine and diminished levels of methionine [72]. There is a long list of situations which put children at special risk of vitamin $\mathrm{B}_{12}$ deficiency; for example, diets low in animal products, synthetic feeding of any description, strict vegetarian diet, small bowel malfunction, gastrectomy, any prolonged illness with disturbance of feeding behavior, especially if combined with increased metabolic demands as systemic malignancy or chemotherapy. Given the scale of use which would result from routine use of $\mathrm{N}_{2} \mathrm{O}$ in children undergoing painful procedures, there should be real concern about the potential for an accident in a child with occult vitamin $\mathrm{B}_{12}$ deficiency. The message must be: never forget vitamin $\mathrm{B}_{12}$ when thinking of using $\mathrm{N}_{2} \mathrm{O}$.

Nitrous oxide also has significant effects on neural cell death in both immature and aging brain as has been shown in experimental animal models. However, the implications for the human fetus and infant, where the brain is maturing at a slower rate than in rodents, remain a matter of ongoing controversy.

A case of neurologic deterioration six days after a single eighty minute exposure to $\mathrm{N}_{2} \mathrm{O}$ occurred in an eighth month old child. A four-month-old child was admitted to hospital because of hypotonia, dehydration, and acidosis three weeks after surgery that had involved a single 180-minute period of anesthesia with $\mathrm{N}_{2} \mathrm{O}$ [73]. Both last children were found to have severe dietary vitamin $B_{12}$ deficiency. The fatal outcome was described in a child aged 3 months with a diagnosis of Type III homocystinuria (5,10-methylenetetrahydro-folate reductase enzyme defect), exposed to $\mathrm{N}_{2} \mathrm{O}$ twice in a period of four days [74]. However, few young patients have a vitamin $B_{12}$ deficiency, but $10 \%$ or more of elderly patients also do have a deficiency. It has been shown that $\mathrm{N}_{2} \mathrm{O}$ increase the plasma homocysteine concentration in adolescents [75] and in adults [76] . It also is the result of inactivation of vitamin $B_{12}$. Also in young children is this effect present for up to 24 hours postoperatively depending on the concentration. and duration of $\mathrm{N}_{2} \mathrm{O}$ administration [77].
In adults has it been proven that such increases can lead to myocardial infarction and stroke $[78,79]$. Such has, however, not been studied in children.

Neuropathy in children after administration has been described [80]. In a study where pediatric patients received $\mathrm{N}_{2} \mathrm{O}$ for up to eight hours during anesthesia was megaloblastic anemia, pancytopenia, thrombocytopenia or leucopenia not found [81]. A single preoperative infusion with vitamin $B_{12}$ and folate was not effective in preventing the increase in total homocysteine caused by nitrous oxide [82]. Lower preoperative vitamin $B_{12}$ or folate levels were not associated with a higher increase in total homocysteine or vice versa. The blood concentration of vitamin $B_{12}$ in personnel in a pediatric emergency department where $\mathrm{N}_{2} \mathrm{O}$ is used with a demand valve, proved to be not different from that in an area where no $\mathrm{N}_{2} \mathrm{O}$ is used at all [83]. However, there still is potential harm for the exposed patient.

\section{Should we still use nitrous oxide in medicine?}

There is in the medical and more specifically in the anesthesia literature regularly a discussion about the need of $\mathrm{N}_{2} \mathrm{O}$ in medical treatments $[84,85,86,87]$. The above mentioned adverse effects are clear and decrease the safety of anesthesia, although their incidence is small. Besides is $\mathrm{N}_{2} \mathrm{O}$ not absolutely needed in anesthesia because there are other methods to obtain stable anesthesia or sedation of patients. Intravenous anesthetics with oxygen-air breathing or artificial ventilation are a very reliable and adequate anesthesia technique. However, these alternatives also have disadvantages. For sedation intermittent or continuous infusion off propofol is an excellent alternative. $\mathrm{N}_{2} \mathrm{O}$ also has some advantages; its onset and emergence are fast, it supports the effects of opioids and other adjuvants, and decreases the rate of intraoperative dosing. The usage of nitrous oxide was reported in $11.9 \%$ of cases, ranging from $0.6 \%$ in Denmark to $38.6 \%$ in Iceland [88]. In the United States $\mathrm{N}_{2} \mathrm{O}$ now used in perhaps $20 \%$ of cases, in Western Europe even in a smaller fraction.

Eliminating $\mathrm{N}_{2} \mathrm{O}$ use will lead to simpler and safer anesthetic delivery devices and installations that could decrease the potential for hypoxia and decrease cost. Use of $\mathrm{N}_{2} \mathrm{O}$ requires specific equipment that must be calibrated, daily-checked and maintained. This is a hidden but real high cost. Pipelines, valves, regulators, flowmeters, and scavenging devices all can and do break; all also require periodic testing. These costs can be eliminated by avoiding the use of $\mathrm{N}_{2} \mathrm{O}$. Besides fatal accidents have happened after maintenance of the $\mathrm{N}_{2} \mathrm{O}$ delivery systems, making wrong connections etc. leading to hypoxia $[89,90]$. As can be concluded from all these arguments am I very reluctant to use $\mathrm{N}_{2} \mathrm{O}$ routinely in anesthesia and sedation. Avoiding $\mathrm{N}_{2} \mathrm{O}$ increase the safety for both patient and personnel.

In 2017 was the matter discussed in the Turkish literature $[91,92]$. The conclusion was that we should stop using $\mathrm{N}_{2} \mathrm{O}$

Conclusions. Nitrous Oxide is not the ideal anesthetic that it was at one time promised to be. The many adverse effects of $\mathrm{N}_{2} \mathrm{O}$ induce an ever recurring discussion whether we should still use it in the medical practice. Its analgesic properties made it popular among anesthesiologists, obstetricians and dentists. Currently is $\mathrm{N}_{2} \mathrm{O}$ besides in anesthesia, frequently used by pediatricians and obstetricians for small interventions and child birth, even without the assistance of an anesthetist [93, 94]. Anesthesia providers currently decrease the use of $\mathrm{N}_{2} \mathrm{O}$ whereas caregivers of other specialties tend to increase the use of it. Self-administration of $\mathrm{N}_{2} \mathrm{O}$ has been advocated by pediatric emergency physicians as provi- 
ding sufficient analgesia [95]. Although they did not find adverse effects in their study population did they clearly warn for the possible occurrence of such effects. Also dentist favor the administration of $\mathrm{N}_{2} \mathrm{O}$ for sedation in pediatric patients. Due to its weak anesthetic effect and the fact that other drugs are more potent anesthetics, can $\mathrm{N}_{2} \mathrm{O}$ easily be replaced by them. This is even more so since we have potent short acting and predictable opioids and other adjuvants for anesthesia available. Modern anesthesia workstations allow low-flow anesthesia decreasing the cost of contemporary and inexpensive inhalation agents. The many serious adverse effects of $\mathrm{N}_{2} \mathrm{O}$ also make its use undesirable. Despite the decrease in use of $\mathrm{N}_{2} \mathrm{O}$ is there apparently increase in the number of adverse effect reports. This is likely due to the fact that in the past a relation between $\mathrm{N}_{2} \mathrm{O}$-exposure and the 4-6 weeks after anesthesia occurring hematologic and neurologic disorders was not recognized. With the current knowledge such relationship and its reporting occurs. Whether $\mathrm{N}_{2} \mathrm{O}$ should still be used in anesthesia is nevertheless a difficult question because $\mathrm{N}_{2} \mathrm{O}$ has some advantages, but also can cause major and minor adverse effects. Especially in patients with possibly a low vitamin $B_{12}$ level should it be avoided. Increased incidence of postoperative nausea and vomiting and the tendency to more postoperative wound infections are only minor ones compared with the more serious hematologic and neurologist disorders that can result. They result from the irreversible inactivation of cobalamin by $\mathrm{N}_{2} \mathrm{O}$ and result in lack of methionine synthetase. Homocysteine accumulation results and is a risk factor for cardioand cerebrovascular disease, thrombosis and stroke, neuronal damage and osteoporosis [96]. Inhibition of methionine synthase induces depletion of intracellular tetrahydrofolate, which may compromise host defense mechanisms, which in turn may explain the increased infection rate [97]. Increased cuff pressure of both endotracheal tubes and laryngeal mask airways from $\mathrm{N}_{2} \mathrm{O}$ diffusion cause damage of vocal cords, trachea and pharynx $[98,99]$. Such does not occur when a pressure release valve is included in the tube [100]. After cessation of the $\mathrm{N}_{2} \mathrm{O}$ administration can the pressure in the cuff decrease exponentially leading to insufficient occlusion and prevention of aspiration and air leak [101]. Also volume expansion of the bowel, increase in the gas inserted in the eye and the increase in the size of pneumothorax are dangerous effects. Animal studies demonstrate that nitrous oxide can cause adverse reproductive effects. Fetal abortion, congenital anomalies, and fetal growth retardation occur in rodents exposed to $\mathrm{N}_{2} \mathrm{O}$ during a major portion of gestation. Also human studies indicate such effects. In addition, $\mathrm{N}_{2} \mathrm{O}$ may alter male germ cells. Results of clinical studies on these topics are so far less clear, however, epidemiological surveys of operating room and dental suite personnel indicate adverse reproductive effects [102, 103]. Increased spontaneous abortion on chronic exposure has been described [104]. In conclusion, there are many minor and major adverse effects to $\mathrm{N}_{2} \mathrm{O}$, although it also has some beneficial effects. Therefore should, in my opinion, $\mathrm{N}_{2} \mathrm{O}$ only be used when absolutely indicated. In all other cases should it be replaced by other, preferably intravenous, agents.

Female anesthetists providing anesthesia mainly in pediatric cases are prone to spontaneous abortion. In 2003 was it demonstrated once more that a higher prevalence of spontaneous abortion in anesthesiologists whose practice is $>75 \%$ pediatrics [105]. Male dentists who worked in offices where $\mathrm{N}_{2} \mathrm{O}$ was used eight hours per week or more had significantly higher incidences of liver, kidney and neurological diseases. Unexposed wives of these dentists had a 1.5-fold increase in spontaneous abortion rates. Female chair-side assistants in these surgeries also had an increased incidence of liver, kidney and neurological disease as well as a 2.3-fold increase in number of spontaneous abortions when compared to dental assistants in control group offices where $\mathrm{N}_{2} \mathrm{O}$ was not used [106, 107]. Many authors of the papers on the adverse effects of $\mathrm{N}_{2} \mathrm{O}$ finish their papers similar to: At the moment, it is premature to suggest that $\mathrm{N}_{2} \mathrm{O}$ should be discontinued as an anesthetic agent. However, the growing body of evidence does support the theory that $\mathrm{N}_{2} \mathrm{O}$ has some neurotoxic and other adverse effects and these results should not be taken lightly. Nitrous oxide is regularly used for neonatal surgery and, as shown, this is a high risk period for neurodevelopment. It is difficult to assess the long term cognitive outcomes in humans, but rat studies suggest long term developmental issues such as memory impairment. It should be remembered that the other inhalation anesthetics (halothane, ethrane, isoflurane, sevoflurane and desflurane) also have adverse effects, many similar to those of $\mathrm{N}_{2} \mathrm{O}$. In my opinion this is another reason not to use $\mathrm{N}_{2} \mathrm{O}$ anymore.

\section{Disclosures:}

The author declare no conflict of interest.

Acknowledgment. I thank Prof. Alexander Obedin for editing a draft of this manuscript.

\section{References}

1. Cohen E. N. Occupational Disease Among Operating Room Personnel: A National Study. Anesthesiology. 1974; $41: 321-340$.

2. Spence A. A., Cohen E. N., Brown B. W. Jr. [et al.] Occupational hazards for operating room-based physicians. Analysis of data from the United States and the United Kingdom. 1977;238:955-959.

3. Duncan P. G., Pope W. D. B., Cohen M. M. [et al.] The safety of anesthesia and surgery during pregnancy. Anesthesiology. 1986;64:790-794.

4. Bodin L., Axelsson G., Ahlborg G. Jr. The association of shift work and nitrous oxide exposure in pregnancy with birth weight and gestational age. Epidemiology. 1999; 10:429-436.

5. Rowland A. S., Baird D. D., Weinberg C. R. [et al.] Reduced fertility among women employed as dental assistants exposed to high levels of nitrous oxide. N. Engl. J. Med. 1992;327:993-997.

6. Gold E. B., Tomich E. Occupational hazards to fertility and pregnancy outcome. Occup. Med. 1994;9:435-469.
7. Hogan K. Nitrous oxide genotoxicity. Anesthesiology. 2013;118:1258-1260

8. Kripke B. J., Kelman A. D., Shah N. K. [et al.] Testicular reaction to prolonged exposure to nitrous oxide. Anesthesiology. 1976;44:104-113

9. Ahlborg G. Jr., Axelsson G., Bodin L. Shift work, nitrous oxide exposure and subfertility among Swedish midwives. Int. J. Epidemiol. 1996;25:783-790.

10. Cohen E. N., Bellville J. W., Brown B. W. Jr. Anesthesia, pregnancy, and miscarriage: a study of operating room nurses and anesthetists. 1971;35:343-347.

11. Askrog V., Harvold B. Teratogenic Effects on Inhalation Anesthetics. Nordisk Medicin. 1970;83:498-500.

12. Cohen E. N., Bellville J. W., Brown B. W. Jr. Anesthesia, pregnancy, and miscarriage: a study of operating room nurses and anesthetists. Anesthesiology. 1971;35:343347.

13. Knill-Jones R. P., Rodrigues L. V., Moir D. D., Spence A. A. Anaesthetic practice and pregnancy. Controlled survey of women anaesthetists in the United Kingdom. Lancet. 1972;1(7764):1326-1328. 
14. Nixon G. S., Helsby C. A., Gordon H., Hytten F. E., Renson C. E. Pregnancy out- come in female dentists. $\mathrm{Br}$. Dent. J. 1979;146:39-42.

15. Cohen E. N., Gift H. C., Brown B. W., Greenfield W., Wu M. L., Jones T. W. [et al.] Occupational disease in dentistry and chronic exposure to trace anesthetic gases. J. Am. Dent. Assoc. 1980; 101:21-31.

16. Buring J. E., Hennekens C. H., Mayrent S. L. [et al.] Health experiences of operating room personnel. Anesthesiology. 1985;62:325-330.

17. Rowland A. S., Baird D. D., Shore D. L., Weinberg C. R., Savitz D. A., Wilcox A. J. Nitrous oxide and spontaneous abortion in female dental assistants. Am. J. Epidemiol. 1995;141:531-538.

18. Axelsson G., Ahlborg G. Jr., Bodin L. Shift work, nitrous oxide exposure, and spontaneous abortion among Swedish midwives. Occup. Environ. Med. 1996;53:374-378.

19. Boscolo A., Milanovic D., Starr J. A. [et al.] Early exposure to general anesthesia disturbs mitochondrial fission and fusion in the developing rat brain. Anesthesiology. 2013;118:1086-1097.

20. Sanchez V., Feinstein S. D., Lunardi N. [et al.] General anesthesia causes long-term impairment of mitochondrial morphogenesis and synaptic transmission in developing rat brain. Anesthesiology. 2011;115:992-1002.

21. Rowland A. S., Baird D. D., Weinberg C. R., Shore D. L., Shy C. M., Wilcox A. J. Reduced fertility among women employed as dental assistants exposed to high levels of nitrous oxide. N. Engl. J. Med. 1992;327:993-97.

22. Bussard D. A. Congenital anomalies and inhalation anesthetics. J. Am. Dent. Assoc. 1976;93:606-609.

23. Rowland A. S., Baird D. D., Shore D. L., Weinberg C. R., Savitz D. A., Wilcox A. J. Nitrous oxide and spontaneous abortion in female dental assistants. Am. J. Epidemiol. 1995; $141: 531-538$

24. Loepke A. W., Soriano S. G. An assessment of the effects of general anesthetics on developing brain structure and neurocognitive function. Anesth. Analg. 2008;106:1681-707.

25. Fink B. R., Shepard T. H., Blandau R. J. Teratogenic activity of nitrous oxide. Nature. 1967;214(5084):146-148.

26. Bussard D. A., Stoelting R. K., Peterson C. [et al.]. Fetal changes in hamsters anesthetized with nitrous oxide and halothane. Anesthesiology. 1974;41:275-278.

27. Bussard D. A. Congenital anomalies and inhalation anesthetics. J. Am. Dent. Assoc. 1976;93:606-609.

28. Corbett T. H., Cornell R. G., Endres J. L. [et al.] Effects of low concentrations of nitrous oxide on rat pregnancy. Anesthesiology. 1973;39:299-301.

29. Bruce D. L., Eide K. A., Linde H. W., Eckenhoff J. E. Causes of death among anesthesiologists: a 20-year survey. Anestehsiology. 1968; 29:565-569.

30. Corbett T. H., Cornell R. G., Lieding K. [et al.] Incidence of cancer among Michigan nurse-anesthetists. Anesthesiology. 1973;3:260-263.

31. Brodsky J. B., Cohen E. N., Whitcher C. [et al.] Occupational exposure to mercury in dentistry and pregnancy outcome. J. Am. Dent. Assoc. 1985;111:779-780.

32. Ermens A. A., Schoester M., Lindemans J. [et al.] Effect of nitrous oxide and methotrexate on folate coenzyme pools of blast cells from leukemia patients. Leuk. Res. 1991; 15:165-171.

33. Ahn W. S., Kim J. Y., Bahk J. H., Park C. D., Kim S. D. Growth Suppression of Leukemic Cells by Hyperbaric Nitrous Oxide and Methotrexate. Korean J. Anesthesiol. 2006;50:308-314.

34. Jung C. H., Sim J. Y., Ahn W. Growth suppression of four cancer cells by hyperbaric nitrous oxide and methotrexate. Korean J. Anesthesiol. 2010;658:61-69.

35. Tramer M., Moore A., McQuay H. Meta-analytic comparison of prophylactic antiemetic efficacy for postoperative nausea and vomiting: Propofol anaesthesia versus omitting nitrous oxide versus total i.v. anaesthesia with propofol. Br. J. Anaesth. 1997;78:256-259.

36. Junger A., Hartmann $B$. Benson $M$. The use of an anesthesia information management system for prediction of antiemetic rescue treatment at the postanesthesia care unit. Anesth. Analg. 2001;92:1203-1209.

37. Apfel C. C., Korttila K., Abdalla M. [et al.] A factorial trial of six interventions for the prevention of postoperative nausea and vomiting. N. Engl. J. Med. 2004;350:24412451.

38. Gan T. Risk Factors for Postoperative Nausea and Vomiting. Anesth. Analg. 2006;102:1884-1898.
39. Bloomfield E., Porembka D., Grimes-Rice M. Avoidance of nitrous oxide and increased isoflurane during alfentanil based anesthesia decreases the incidence of postoperative nausea. Anesth Prog. 1997;44:27-31.

40. Fernández-Guisasola J., Gómez-Arnau J.I., Cabrera Y., del Valle S.G. Association between nitrous oxide and the incidence of postoperative nausea and vomiting in adults: a systematic review and meta-analysis. Anaesthesia. 2010;65:379-387.

41. Apfel C. C., Korttila K., Abdalla M. [et al.] A factorial trial of six interventions for the prevention of postoperative nausea and vomiting. N. Engl. J. Med. 2004;350:24412451.

42. Yi M. S., Kang H., Kim M. K. [et al.] Relationship between the incidence and risk factors of postoperative nausea and vomiting in patients with intravenous patientcontrolled analgesia. Asian J. Surg. 2017 Mar 31. pii: S1015-9584(16)30464-X [Epub ahead of print]

43. Peyton P. J., Horriat M., Robinson G. J. [et al.] Magnitude of the second gas effect on arterial sevoflurane partial pressure. Anesthesiology. 2008;108:381-387.

44. Dubois M. C., Piat V., Constant I. [et al.] Comparison of three techniques for induction of anaesthesia with sevoflurane in children. Paediatr. Anaesth. 1999:9:19-23.

45. Murray D. J., Mehta M. P., Forbes R. B. [et al.] Additive contribution of nitrous oxide to halothane MAC in infants and children. Anesth. Analg. 1990;71:120-124.

46. Kihara S., Yaguchi Y., Inomata S. [etal.] Influence of nitrous oxide on minimum alveolar concentration of sevoflurane for laryngeal mask insertion in children. Anesthesiology. 2003:99:1055-1058

47. Swan H. D., Crawford M. W., Pua H. L. [et al.] Additive contribution of nitrous oxide to sevoflurane minimum alveolar concentration for tracheal intubation in children. Anesthesiology. 1999;91:667-671.

48. Fisher D. M., Zwass M. S. MAC of desflurane in $60 \%$ nitrous oxide in infants and children. Anesthesiology.1992; 76:354-356.

49. Murray D. J., Mehta M. P., Forbes R. B. The additive contribution of nitrous oxide to isoflurane MAC in infants and children. Anesthesiology. 1991;75:186-190.

50. Davidson J. A., Macleod A. D., Howie J. C. [et al.] Effective concentration 50 for propofol with and without $67 \%$ nitrous oxide. Acta Anaesthesiol. Scand. 1993;37:458464.

51. Ng J. M., Hwang N. C. Inhaling nitrous oxide reduces the induction dose requirements of propofol. Anesth. Analg. 2000;90:1213-1216.

52. McCann W., Wilson S., Larsen P. [et al.] The effects of nitrous oxide on behavior and physiological parameters during conscious sedation with a moderate dose of chloral hydrate and hydroxyzine. Pediatr. Dent. 1996;18:35-41.

53. Litman R. S., Kottra J. A., Verga K. A. [et al.] Chloral hydrate sedation: the additive sedative and respiratory depressant effects of nitrous oxide. Anesth. Analg. 1998;86:724-728

54. Ghouri A. F., White P. F. Effect of fentanyl and nitrous oxide on the desflurane anesthetic requirement. Anesth. Analg. $1991 ; 72: 377-781$

55. Albertin A., Casati A., Bergonzi P. [et al.] Effects of two target-controlled concentrations (1 and $3 \mathrm{ng} / \mathrm{ml}$ ) of remifentanil on MAC(BAR) of sevoflurane. Anesthesiology. 2004:100:255-259.

56. Doyle W. J., Banks J. M. Middle ear pressure change during controlled breathing with gas mixtures containing nitrous oxide. J. Appl. Physiol. 2003;94:199-204.

57. Murray D. J., Forbes R. B., Dull D. L. [et al.] Hemodynamic responses to nitrous oxide during inhalation anesthesia in pediatric patients. J. Clin. Anesth. 1991;3:14-19.

58. Inada T., Inada K., Kawachi S. [et al.] Haemodynamic comparison of sevoflurane and isoflurane anaesthesia in surgical patients. Can. J. Anaesth. 1997;44:140-145.

59. Kinouchi K., Fukumitsu K., Tashiro C. [et al.] Duration of apnoea in anaesthetized children required for desaturation of haemoglobin to $95 \%$ : comparison of three different breathing gases. Paediatr. Anaesth. 1995;5:115-119.

60. Elwood T., Hutchinson E. Oxygen in nitrogen versus nitrous oxide during pediatric general anesthesia. Acta Anaesthesiol. Sin. 2001;39:59-64.

61. Burnweit C., Diana-Zerpa J. A., Nahmad M. H. [et al.] Nitrous oxide analgesia for minor pediatric surgical procedures: an effective alternative to conscious sedation? J. Pediatr. Surg. 2004;39:495-499. 
62. Tobias J. D. Applications of nitrous oxide for procedural sedation in the pediatric population. Pediatr. Emerg. Care. 2013;29:245-265

63. Foley J. A prospective study of the use of nitrous oxide inhalation sedation for dental treatment in anxious children. Eur. J. Paediatr. Dent. 2005;6:121-128.

64. Lyratzopoulos G., Blain K. M. Inhalation sedation with nitrous oxide as an alternative to dental general anaesthesia for children. J. Public Health Med. 2003;25:303-312.

65. Gregory P. R., Sullivan J. A. Nitrous oxide compared with intravenous regional anesthesia in pediatric forearm fracture manipulation. J. Pediatr. Orthop. 1996;16:187-191.

66. Migita R. T., Klein E. J., Garrison M. M. Sedation and analgesia for pediatric fracture reduction in the emergency department: a systematic review. Arch. Pediatr. Adolesc. Med. 2006;160:46-51.

67. Fishman G., Botzer E., Marouani N., De Rowe A. Nitrous oxide-oxygen inhalation for outpatient otologic examination and minor procedures performed on the uncooperative child. Int. J. Pediatr. Otorhinolaryngol. 2005;69:501-504

68. Zier J. L., Kvam K. A., Kurachek S. C. [et al.] Sedation with nitrous oxide compared with no sedation during catheterization for urologic imaging in children. Pediatr. Radiol. 2007;37:678-684.

69. Henderson J. M., Spence D. G., Komocar L. M. [et al.] Administration of nitrous oxide to pediatric patients provides analgesia for venous cannulation. Anesthesiology. 1990;72:269-271.

70. Fauroux B., Onody P., Gall O. [et al.] The efficacy of premixed nitrous oxide and oxygen for fiberoptic bronchoscopy in pediatric patients: a randomized, double-blind, controlled study. Chest. 2004;125:315-321.

71. Michaud L., Gottrand F., Ganga-Zandzou P. S. [et al.] Nitrous oxide sedation in pediatric patients undergoing gastrointestinal endoscopy. J. Pediatr. Gastroenterol. Nutr. 1999;28:310-314.

72. Baum V. C. When nitrous oxide is no laughing matter: nitrous oxide and pediatric anesthesia. Paediatr. Anaesth. 2007; 17:824-830

73. McNeely J. K., Buczulinski B., Rosner D. R. Severe neurological impairment in an infant after nitrous oxide anesthesia. Anesthesiology. 2000;93:1549-1550.

74. Selzer R. R., Rosenblatt D. S., Laxova R. [et al.] Adverse effect of nitrous oxide in a child with 5,10 -methylenetetrahydrofolate reductase deficiency. $N$. Engl. J. Med. 2003;349:45-50.

75. Nagele P., Tallchief D., Blood J. [et al.] Nitrous oxide anesthesia and plasma homocysteine in adolescents. Anesth. Analg. 2011; 113:843-848.

76. Foschi D., Rizzi A., Zighetti M. L. [et al.] Effects of surgical stress and nitrous oxide anaesthesia on peri-operative plasma levels of total homocysteine. A randomised, controlled study in general surgery. Anaesthesia. 2001;56:676-679.

77. Pichardo D., Luginbuehl I. A., Shakur Y. [et al.] Effect of nitrous oxide exposure during surgery on the homocysteine concentrations of children. 2012;117:15-21.

78. Myles P. S., Chan M. T., Leslie K. [et al.] Effect of nitrous oxide on plasma homocysteine and folate in patients undergoing major surgery. Br. J. Anaesth. 2008;100:780-786.

79. Badner N. H., Beattie W. S., Freeman D. [et al.] Nitrous oxide-induced increased homocysteine concentrations are associated with increased postoperative myocardial ischemia in patients undergoing carotid endarterectomy. Anesth. Analg. 2000;91:1073-1079.

80. McNeely J. K., Buczulinski B., Rosner D. R. Severe neurological impairment in an infant after nitrous oxide anesthesia. Anesthesiology. 2000;93:1549-1550.

81. Duma A., Cartmill C., Blood J. [et al.] The hematological effects of nitrous oxide anesthesia in pediatric patients. Anesth. Analg. 2015;120:1325-1330.

82. Rao L. K., Francis A. M., Wilcox U., Miller J. P. [et al.] Preoperative vitamin $B$ infusion and prevention of nitrous oxide-induced homocysteine increase. Anaesthesia. 2010;65:710-715.

83. Staubli G., Baumgartner M., Sass J. O. [et al.] Laughing Gas in a Pediatric Emergency Department-Fun for All Participants: Vitamin B12 Status Among Medical Staff Working With Nitrous Oxide. Pediatr. Emerg. Care. 2016;32:827-829.
84. Shaw A. D. S., Morgan M. Nitrous oxide: time to stop laughing? Anaesthesia. 1998:53:213-215.

85. Schönherr M., Hollmann M., Graf B. Lachgas - Sinn oder Unsinn für die heutige Narkoseführung. Anaesthesist. 2004;53:796-812.

86. Schwilden $\mathrm{H}$. Schüttler J. 200 Jahre Lachgas - Auch das Ende einer Ära? Anasthesiol. Intensivmed. Notfallmed. Schmerzther. 2001;36:640.

87. Carter J. A., McAteer P. Nitrous oxide. 2001:56:705-706.

88. Husum B., Stenqvist O., Alahuhta S. [et al.] Current use of nitrous oxide in public hospitals in Scandinavian countries. Acta Anaesthesiol. Scand. 2013;57:1131-1137.

89. Herff H., Paal P., von Goedecke A. [et al.] Fatal errors in nitrous oxide delivery. Anaesthesia. 2007;62:1202-1206.

90. Jackson T. How the media report medical errors. Blunders will never cease. British Medical Journal. 2001; 322:562.

91. Rossaint R., Coburn M., Jantzen J. P. Should we Still use Nitrous Oxide in our Clinical Practice? No! Turk. J. Anaesthesiol. Reanim. 2017;45:3-5.

92. Rossaint R., Coburn M., Jantzen J. P. Should we Still use Nitrous Oxide in our Clinical Practice? No! Rebuttal to Daniel Sessler «Pro Nitrous oxide». Turk. J. Anaesthesiol. Reanim. 2017;45:6.

93. Frampton A., Browne G. J. Lam L. T. [et al.] Nurse administered relative analgesia using high concentration nitrous oxide to facilitate minor procedures in children in an emergency department. Emerg. Med. J. 2003;20:410-413.

94. Ekbom K Jakobsson J. Marcus C. Nitrous oxide inhalation is a safe and effective way to facilitate procedures in paediatric outpatient departments. Arch. Dis. Child. 2005;90:1073-1076.

95. Heinrich M., Menzel C., Hoffmann F. [et al.] Selfadministered procedural analgesia using nitrous oxide/ oxygen (50:50) in the pediatric surgery emergency room: effectiveness and limitations. Eur. J. Pediatr. Surg. 2015; 25:250-256

96. Wald D. S., Law M., Morris J. K. Homocysteine and cardiovascular disease: evidence on causality from a meta-analysis. Br. Med. J. 2002;325:1202-1208.

97. Chen Y., Liu X., Cheng C. H. K, Gin T., Leslie K., Myles P. S. [et al.] Leukocyte DNA damage and wound infection after nitrous oxide administration: A randomized controlled trial. Anesthesiology. 2013;118:1322-1331.

98. Nguyen H., Tu H., Saidi N. [et al.] Nitrous oxide increases endotracheal cuff pressure and the incidence of tracheal lesions in anesthetized patients. Anesth. Analg. 1999:89:187-190

99. Atalay C., Aykan S., Can A. [et al.] Tracheal rupture due to diffusion of nitrous oxide to cuff of high-volume, lowpressure intubation tube. EAJM. 2009;41:136-139.

100. Dullenkopf A., Gerber A. C., Weiss M. Nitrous oxide diffusion into tracheal tube cuffsefficacy of a new prototype cuff pressure release valve. Acta Anaesthesiol. Scand. 2005;49:1072-1076.

101. Karasawa F., Mori T., Kawatani Y. [et al.] Deflationary phenomenon of the nitrous oxide-filled endotracheal tube cuff after cessation of nitrous oxide administration. Anesth. Analg. 2001:92:145-148.

102. Ahlborg G., Axelsson G., Bodin L. Shift work, nitrous oxide Exposure and subfertility among Swedish Midwives. Int. J. Epidemiol. 1996;25:783-790.

103. Rowland A. S., Baird D. D., Shore D. L. [et al.] Nitrous oxide and spontaneous abortion in female dental assistants. Am. J. Epidemiol. 1995;141:531-538.

104. Rowland A. S., Baird D. D., Weinberg C. R. [et al.] Reduced fertility among women employed as dental assistants exposed to high levels of nitrous oxide. N. Engl. J. Med. 1992;327:993-997.

105. Gauger V. T., Voepel-Lewis T., Rubin P. [et al.] A survey of obstetric complications and pregnancy outcomes in paediatric and nonpaediatric anaesthesiologists. Paediatr. Anaesth. 2003;13:490-495.

106. Booij Leo H. D. H. J. The history of nitrous oxide. Should it still be used in pediatric medicine? (Part I). Medical News of North Caucasus. 2017;12(3):347-354 https://doi.org/10.14300/mnnc.2017.12074

107. Cohen E. N., Gift H. C., Brown B. W. [et al.] Occupational disease in dentistry and chronic exposure to trace anesthetic gases. J. Am. Dent. Assoc. 1980;101:21-31.

\section{About author}

Booij Leo H. D. Hj., MD, PhD, FRCA, Professor emeritus of the Department of Anesthesia, Pain Treatment and Palliative Care

e-mail: Ihdj.booij@upcmail.nl 